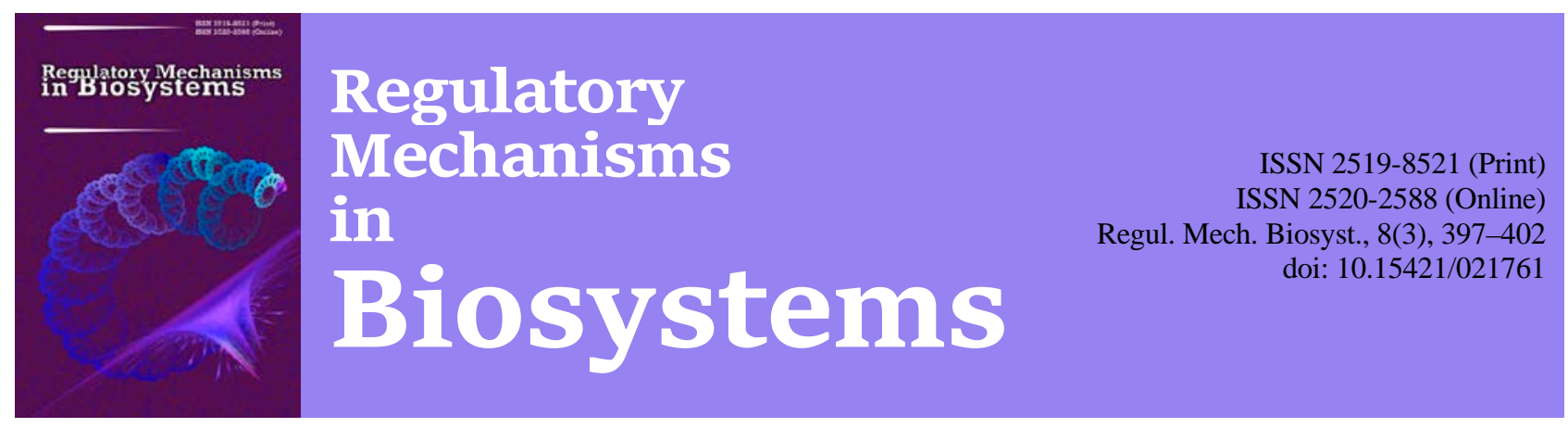

\title{
Mechanism of changes of peripheral neuromuscular endings of the tongues of rats with experimental streptozotocyn diabetes mellitus
}

\author{
M. Luchynskyi, V. Luchinskyi, V. Shcherba, A. Demkovych, Y. Luchinska \\ I. Horbachevsky Ternopil State Medical University, Ternopil, Ukraine
}

Article info

Received 14.06.2017

Received in revised form 18.08.2017

Accepted 19.08.2017

I. Horbachevsky Ternopil State Medical University, Chekhov Str., 3, Ternopil, 46003, Ukraine.

Tel. +38-067-415-60-87.

E-mail: luch1959@ukr.net
Luchynskyi, M., Luchinskyi, V., Shcherba, V., Demkovych, A., \& Luchinska, Y. (2017). Mechanism of changes of peripheral neuromuscular endings of the tongues of rats with experimental streptozotocyn diabetes mellitus. Regulatory Mechanisms in Biosystems, 8(3), 397-402. doi: 10.15421/021761

This paper presents the characteristics of dynamics of morphological changes of neuromuscular endings of the tongues of rats with experimentally induced streptozotocin diabetes mellitus. The hysto-ultrastructural research showed pathomorphological changes in different periods of the experimental diabetes mellitus. The patterns of these changes indicate the close interrelation between neuromuscular endings and elements of muscular tissues. During experimental streptozotocin diabetes mellitus, there occured interconnected structural changes of muscle fibers, myelin nerve fibers and the microcirculatory channel of the tongue with damage to the neuromuscular endings. In the dynamics of the diabetic process, three phases were distinguished: the phase of reactive-dystrophic changes with maximum severity two weeks after the beginning of the experimental modeling of streptozotocin diabetes mellitus; the phase of destructive-dystrophic processes, which began after the fourth week from the beginning of the modeling of experimental streptozotocin diabetes; the degenerative-destructive phase, which developed after the sixth week of the experiment. The dynamics of changes in the neuromuscular endings are also related to the duration of diabetes mellitus, they occur in two stages: in the first stage (up to 4 weeks) reactive processes were observed, in the second (6-8 weeks) - dystrophic processes. The uneven degree of their manifestation is related to the reaction of the microcirculatory channel of neuromuscular endings and composition of the tongue muscles. The greatest sensitivity to hyperglycemia was observed in muscle fibers of the intermediate type.

Keywords: diabetes mellitus; neuro-muscle endings; tongue

\section{Механізм змін у периферичному нервово-м'язовому апараті язика за експериментального стрептозотоцинового цукрового діабету}

\author{
М. А. Лучинський, В. М. Лучинський, В. В. Щерба, А. Є. Демкович, Ю. І. Лучинська
}

Тернопільський державний медичний університет імені I. Я. Горбачевського МОЗ Украӥни, Тернопіль, Україна

\begin{abstract}
Наведено характеристику динаміки морфологічних змін нервово-м’язових закінчень язика за експериментального стрептозотоцинового цукрового діабету. У результаті гісто-ультраструктурного дослідження показано патоморфологічні зміни в різні терміни експериментального цукрового діабету, а їх закономірність вказує на тісний контакт нервово-м'язових закінчень і елементів м'язової тканини. За експериментального стрептозотоцинового цукрового діабету відбувається поєднана структурна перебудова м'язових волокон, мієлінових нервових волокон і мікроциркуляторного русла язика з порушенням нервово-м'язових закінчень. У динаміці діабетичного процесу виділено три фази: фазу реактивно-дистрофічних змін із максимальною вираженістю через два тижні від початку моделювання експериментального стрептозотоцинового цукрового діабету, фазу деструктивно-дистрофічних процесів, яка починається після четвертого тижня від початку моделювання експериментального стрептозотоцинового цукрового діабету, дегенеративно-деструктивну фазу, яка розвивається після 6-го тижня досліду. При цьому динаміка змін у самих нервово-м’язових закінченнях також залежить від тривалості цукрового діабету, які проходять у дві стадії: у першій стадії (до 4 тижнів) спостерігаються реактивні, у другій (6-8-й тижні) - дистрофічні процеси. Неоднаковий ступінь їх вираженості пов'язаний із реакцією власного мікроциркуляторного русла нервово-м’язових закінчень і композицією м’язів язика. Найбільшу чутливість до гіперглікемії виявляють м'язові волокна проміжного типу.
\end{abstract}

Ключові слова: цукровий діабет; нервово-м’язові закінчення; язик Вступ

Структурно-функціональні особливості язика визначають різноманітні клінічні варіанти його змін за багатьох соматичних захворювань і це вже давно привертає увагу вчених різних спе-

ціалізацій (Sanders and Mu, 2013; Pourlis, 2014). За даними Popel' et al. (2017) установлено, що нервово-трофічний компонент відіграє важливу роль у патогенезі дистрофічних і запальних уражень язика за цукрового діабету I типу, але механізми розвитку цих процесів вивчені недостатньо. 
Розвиток експериментального цукрового діабету I типу моделюють шляхом внутрішньоочеревного введення стрептозотоцину, що супроводжується гіперглікемією різного ступеня важкості. Проблемі впливу гіперглікемії на різні органи та тканини організму людини та тварин присвячена низка наукових досліджень (O’Reilly and Long, 2008; Meo, 2009; Abdel-Reheim et al., 2014; Rukavina, 2016). Гіперглікемія змінює не тільки метаболізм м'язів, a й їх структуру (Westfall et al., 2015). Особливе місце серед проявів цукрового діабету посідає ураження нервово-м'язового апарату та судин мікроциркуляторного русла (Rezki et al., 2016). Нині відомості про зміни рухових нервово-м'язових закінчень язика та ïx мікроциркуляторного русла за експериментального стрептозотоцинового цукрового діабету фрагментарні та вимагають узагальнення (Uemura, 2009; Jackowiak et al., 2014).

Донині не створено спільної точки зору відносно характеру патологічних змін мієлінових нервових волокон за діабетичного глоситу (Byrd et al., 2003; O’Reilly and Long, 2008). Одні дослідники дотримуються думки, що такі зміни - первинні (Nwayyir, 2017; Rehman and Akash, 2017), інші відносять їх до вторинних, які розвиваються внаслідок порушення місцевого кровообігу (Tooke, 2003; Uemura et al., 2009), треті - дотримуються теорії порушення нейрогуморальної регуляції місцевого метаболізму мієлінових нервових волокон (Pertseva et al., 2013). При цьому всі одностайно визнають швидкоплинність і зворотність процесів за вираженого характеру деструкції складових компонентів нервових провідників (Westfall et al., 2015). При цьому відсутні дані про зміни рухових закінчень у власних м'язах язика.

Тому, у світлі сучасних запитів практичної нейростоматології, вивчення механізмів структурно-адаптивних змін в окремих структурних компонентах язика за експериментального стрептозотоцинового цукрового діабету становлять значний інтерес (Abdel-Reheim et al., 2014).

Мета цієї статті - оцінити динаміку морфологічних змін нервово-м'язових закінчень язика, їх мікроциркуляторного русла за експериментального стрептозотоцинового цукрового діабету.

\section{Матеріал і методи досліджень}

Досліджували язик 45 лабораторних щурів лінії Вістар. Контрольна група складалася з 20 інтактних тварин. Цукровий діабет моделювали шляхом внутрішньочеревного введення 0,1 мл розчину стрептозотоцину (Colev, 2008; Semenko and Savytskyi, 2017). Для дослідження нервових і м'язових волокон язика застосовували гістологічний (забарвлення гематоксиліном i еозином, імпрегнація за Більшовським - Грос, методом Маркі) та електронно-мікроскопічний методи. Всі мієлінові нервові волокна за розміром поділяли на дрібні (1,0-4,0 мкм), середні (4,1-7,0 мкм) і великі (понад 7,0 мкм). Індекс g визначали за формулою $\mathrm{g}=$ à , де

a-діаметр аксона, $\mathrm{d}$ - діаметр цілого МНВ.

Тварин у період дослідження утримували на стандартному раціоні віварію та виводили з експерименту через 2, 4, 6 і 8 тижнів від початку моделювання експериментального стрептозотоцинового цукрового діабету згідно «Правил гуманного поводження 3 експериментальними тваринами» та «Загальними етичними принципами експериментів на тваринах».

Результати дослідження оброблені за допомогою пакета прикладних програм для медико-біологічних досліджень Statistica 6.0 (StatSoft Inc., USA). Вірогідність різниці між вибірками оцінювали за t-критерієм Стьюдента, з перевіркою нормальності розподілу. Різницю вважали вірогідною за $\mathrm{P}<0,05$.

\section{Результати}

У перші два тижні після початку моделювання експериментального стрептозотоцинового цукрового діабету в термінальних мієлінових нервових волокнах утворюються варикозні розширення, що на ультраструктурному рівні пов'язано з розшаруванням мієлінової оболонки. Відбувається вакуолізація цитоплазми ней- ролемоцитів, а в аксонах зменшується щільність матриксу мітохондрій і розширюється периаксональний простір. При цьому у претермінальних ділянках зменшується кількість розгалужень рухового аксона. У нервово-м'язових закінченнях зменшується периметр терміналі аксона, довжина синаптичних контактів, ширина активних зон, кількість синаптичних пухирців, фрагментуються кристи мітохондрій, збільшується відстань між синаптичними складками (рис. 1).

Через два тижні від початку моделювання експериментального стрептозотоцинового цукрового діабету ядра м'язових волокон мають множинні інвагінації каріолеми, хроматин конденсований переважно на периферії нуклеоплазми. При цьому саркоплазма має знижену електронно-оптичну щільність та містить велику кількість вакуолей, частково втрачається поперечна смугастість. Такі зміни характерні переважно для м'язових волокон проміжного типу.

Через чотири тижні після початку моделювання експериментального стрептозотоцинового цукрового діабету в окремих мієлінових нервових волокнах дрібного та середнього діаметра спостерігаються периаксональні зміни у вигляді набряку та часткового руйнування мієлінової оболонки. Внаслідок цього виявляється їх нерівномірне забарвлення. Підтвердження цього - їх метричний перерозподіл (збільшення кількості середніх і великих за зменшення кількості дрібних нервових волокон) і зменшення показника g до 0,32 ум. од. (у контролі показник g становить 0,48 ум. од.). Претермінальні ділянки рухових аксонів утворюють локальні звуження та варикозні розширення, зменшується площа їх термінальних розгалужень.

В аксоплазмі термінальних мієлінових нервових волокон поряд із вищезгаданими змінами зростає ступінь агрегації філаментозно-тубулярних структур. При цьому виникає дезінтеграція більшості складок постсинаптичної мембрани, розширення синаптичної щілини та вростання в неї відростків кінцевих нейролемоцитів (рис. 2). У нервово-м'язових закінченнях зменшується кількість синаптичних пухирців та мітохондрій, вони мають просвітлений матрикс і зруйновані кристи. В цей термін з початку моделювання експериментального стрептозотоцинового цукрового діабету супроводжується зменшенням периметра терміналі та довжини синаптичного контакту відповідно на $39,7 \%$ i $41,9 \%$ (P < 0,05).

Отримані дані свідчать про зниження інтенсивності цих процесів за експериментального стрептозотоцинового цукрового діабету. У постсинаптичному відділі зменшується до 64,9\% кількість синаптичних складок, відстань між ними зростає в 1,7 раза, ширина активних зон зменшується на 41,6\% (P < 0,05).

Через чотири тижні після початку моделювання експериментального стрептозотоцинового цукрового діабету в м'язових волокнах наростає набряк саркоплазми, який викликає розшарування міофібрил. У 25,5\% випадків у м'язових волокнах проміжного типу спостерігаються ядра із значним зменшенням осміофільності нуклеоплазми.

У цей термін починає яскраво проявлятись реакція кровоносного русла у вигляді звуження просвіту судин мікроциркуляторного русла, збільшенням кількості функціонуючих артеріоло-венозних анастомозів. Через це зменшується кількість внутрішньостовбурових капілярів та їх сумарна ємкість відповідно на $26,5 \%$ та $12,7 \%$, тоді як площа «зон васкуляризації» одним внутрішньом'язовим гемокапіляром збільшується в середньому на $12,2 \%$ ( $>0,05)$. Це викликає збільшення на 22,5\% кількості м'язових волокон, які припадають на один гемокапіляр, розташований у цій зоні.

Картина перебудови периферичного нервового апарату язика через шість тижнів після початку моделювання експериментального стрептозотоцинового цукрового діабету досить строката, що проявляється помітним набряком і нерівномірною імпрегнацією мієліну у 28,1\% мієлінових нервових волокон, тоді як в інших волокнах $(18,2 \%)$ зміни стосуються більшою мірою аксонів як мієлінових, так і безмієлінових нервових волокон. Обробка мієлінових нервових волокон методом Маркі дозволяє виявити значну кількість недоокиснених продуктів розпаду мієліну (у 15,4\% мієлі- 
нових нервових волокон). Ще одна група мієлінових нервових волокон (10,2\%) характеризується вираженим набряком і вакуолізацією мієлінової оболонки. Це - причина її нерівномірного забарвлення за рахунок порушення дрібнокоміркової структури. В окре- мих мієлінових нервових волокнах, які складають 8,3\% від їх загальної кількості, відбувається локальна деструкція мієлінової оболонки та сегментарне оголення аксонів. Ще 19,8\% мієлінових нервових волокон залишаються інтактними.

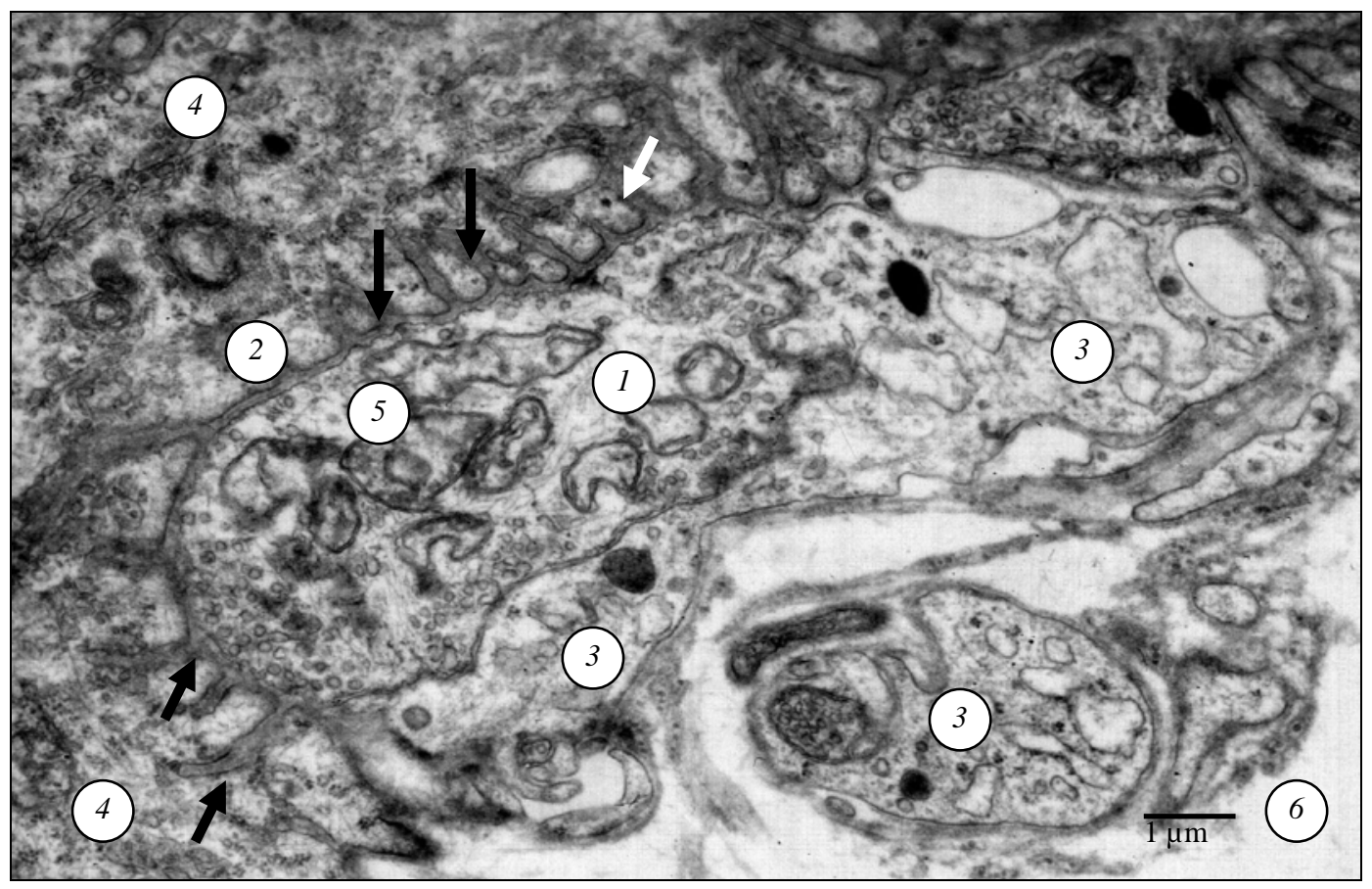

Рис. 1. Ультраструктура нервово-м'язового синапсу язика щура через два тижні після початку моделювання стрептозотоцинового цукрового діабету (стрілками показані постсинаптичні складки): 1 - пресинаптичний полюс, 2 - постсинаптичний полюс, 3 - кінцевий нейролемоцит, 4 - саркоплазма, 5 - мітохондрії, 6 - ендомізій

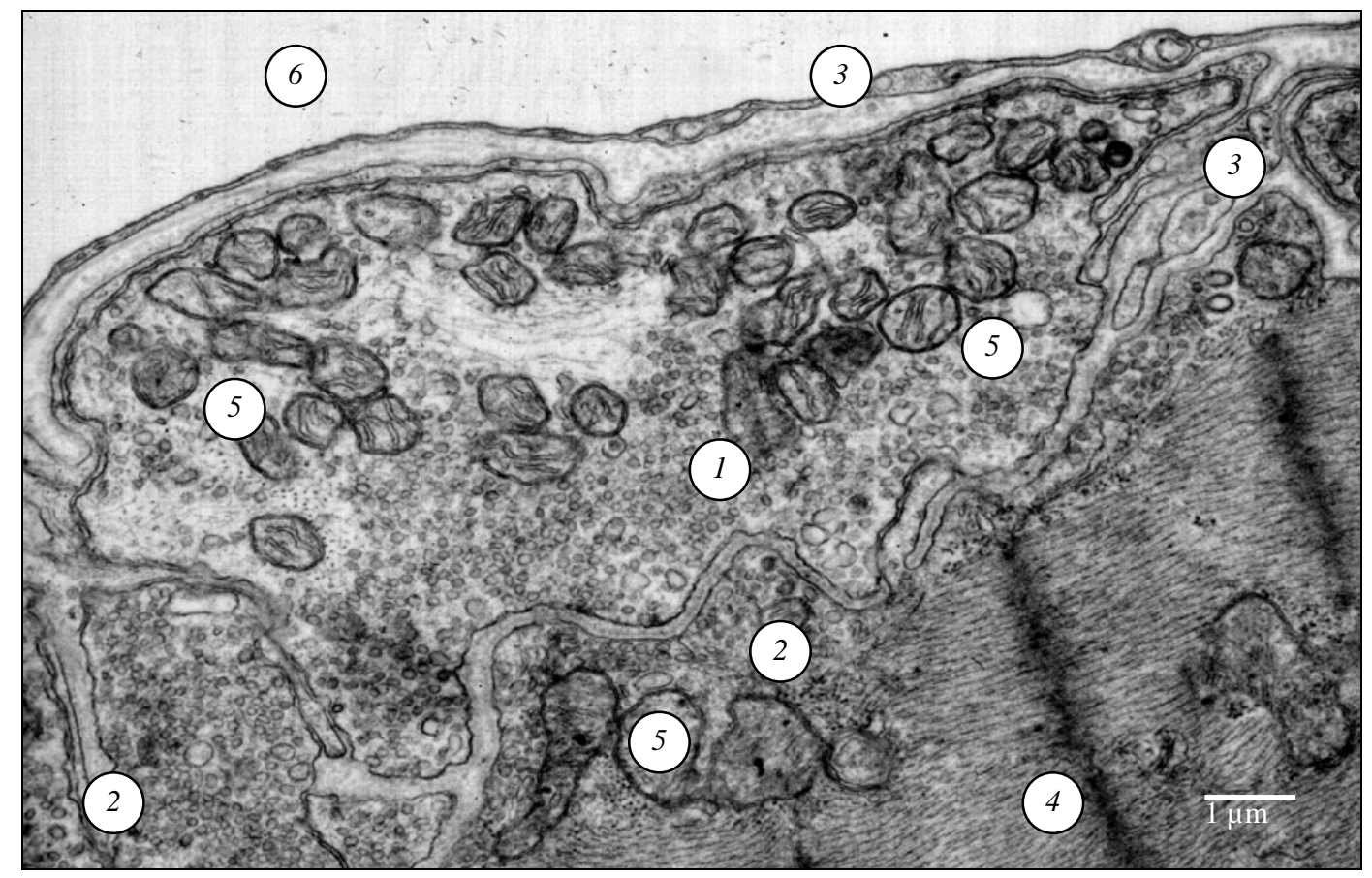

Рис. 2. Ультраструктура нервово-м’язового синапсу язика щура через чотири тижні після початку моделювання стрептозотоцинового цукрового діабету (стрілками показані постсинаптичні складки): 1 - пресинаптичний полюс, 2 - постсинаптичний полюс, 3 - відросток кінцевого нейролемоцита, 4 - саркоплазма, 5 - мітохондрії, 6 - ендомізій

Морфометричний аналіз, проведений на препаратах, забарв-

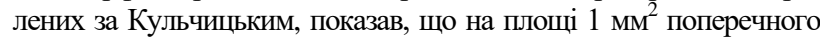
перерізу язика внаслідок демієлінізації аксонів зменшується загальна кількість мієлінових нервових волокон.

Середня площа нервово-м'язових закінчень зменшується порівняно 3 контролем на 56,1\%, а порівняно 3 даними попереднього терміну експерименту - на 25,6\% (P <0,05). Аксоплазма переван- тажена синаптичними пухирцями. Їх кількість на весь зріз через активну зону синапсу зростає в 3,6 раза порівняно $з$ контрольними показниками та на 37,8\% більше, ніж на етапі чотирьох тижнів після початку моделювання експериментального стрептозотоцинового цукрового діабету. У субсинаптичній зоні визначається зменшення кількості рибосом і полірибосом, але збільшується кількість піноцитозних пухирців. При цьому зменшується кіль- 
кість складок постсинаптичної мембрани, а отже і їі площі. У цей термін експерименту продовжуються процеси деструкції окремих мієлінових нервових волокон. При цьому в ділянці нервово-м’язових закінчень зменшується кількість нейролемоцитів, збільшується аргірофілія їх ядер.

$\mathrm{У}$ цей час за рахунок розвитку вираженої вазоконстрикції відбувається розрідження судинної сітки язика, iї капілярні петлі збілышуються у розмірах до 100-140 x 70-80 мкм, а кількість внутрішньом'язових гемосудин зменшується до 53,2 $\pm 2,14$ на 1 мм² поперечного перерізу язика. Внаслідок зменшення діаметра просвіту складових частин гемомікроциркуляторного русла язика відбувається метричний перерозподіл гемокапілярів: значно зменшується кількість великих та збільшується дрібних і середніх за діаметром мікросудин. Унаслідок зменшення діаметра приносних судин гемомікроциркуляторного русла частина крові скидається через відкриті аретеріоло-венозні шунти.

У зв'язку зі зменшенням кількості внутрішьом'язових гемокапілярів віддаль між ними та радіус їх кровопостачання порівняно 3 тваринами контрольної групи збільшуються на 14,6\%, що викликає розширення «зон васкуляризації» кожного з них та збільшення кількості нервових волокон в їх межах. Порівняно 3 тваринами контрольної групи у щурів експериментальної групи сумарна ємність кровоносного русла зменшується на $25,5 \%$ і складає 9954 мкм $^{3}$.

Через вісім тижнів після початку моделювання експериментального стрептозотоцинового цукрового діабету мієло- та ангіоархітектоніка язика значно відрізняється від такої у тварин контрольної групи. Поряд із цим загальна кількість мієлінових нервових волокон порівняно з попереднім терміном (хоча не вірогідно) все ж залишається меншою (P > 0,05). Менше, порівняно 3 контрольною групою, нараховується мієлінових нервових волокон великого діаметра, тоді як кількість дрібних нервових волокон із витонченою мієліновою оболонкою більша, що підтверджує існування процесів демієлінізації. Показник g зменшується в усіх метричних групах мієлінових нервових волокон і складає 0,28 ум. од. Нейролемоцити таких нервових волокон містять ядра дрібного розміру з маргінально розподіленим хроматином.

У цей термін виявляються масові руйнування нервово-м'язових закінчень, гомогенізація мієлінових оболонок, атрофія термінальних розгалужень аксонів. Аксоплазма електроннощільна, в ній відсутні мікротрубочки.

У нервово-м'язових закінченнях термінальні розгалуження руйнуються, в результаті чого пресинаптичний полюс відсутній. У цих ділянках спостерігаються залишки аксоплазми. На цьому етапі експерименту спостерігали формування так званих атрофічних нервово-м'язових закінчень, для яких характерна ознака - периферичне розташування дрібних синаптичних пухирців 3 утворенням великих безпухирцевих зон у центральній частині аксоплазми та повна відсутність складок постсинаптичної мембрани.

Гіперглікемія, яка розвивається під час моделювання експериментального стрептозотоцинового цукрового діабету, протягом восьми тижнів, викликає деструкцію міофіламентів, що супроводжується порушенням структури M- i Z-ліній у міофібрилах. Мітохондрії зменшуються в розмірах, їх матрикс має низьку електронно-оптичну щільність, кристи дезорієнтовані, вкорочені, фрагментовані. У саркоплазмі переважно м'язових волокон проміжного типу спостерігається збільшення кількості включень різної електронно-оптичної щільності.

У кровоносному руслі язика у цей термін зберігається тенденція до зменшення просвіту його складових частин. При цьому діаметр просвіту судин артеріальної частини вірогідно відрізняється від норми, тоді як його венозна частина залишається розширеною. Все ж морфометрично встановлено зменшення кількості великих $\mathrm{i}$ середніх та збільшення числа дрібних гемокапілярів, збілышення середнього радіуса та площі зони кровопостачання кожного з них, зменшення сумарної ємності кровоносного русла. При цьому відносна кількість мієлінових нервових волокон на один гемокапіляр та їх кількість у «зонах васкуляризації» менша на 10,6\%, ніж у попередній термін, і на 37,2\%, ніж у тварин контрольної групи (Р <
0,05). Між кількісним і якісним складом мієлінових нервових волокон і гемокапілярів відмічається низька кореляційна залежність $(\mathrm{r}=0,28)$, що свідчить про зменшення взаємозумовленості мієло- та ангіоархітектоніки язика за стрептозотоцинового цукрового діабету.

\section{Обговорення}

Нині накопичено значні знання та опубліковано достатню кількість результатів досліджень, присвячених морфофункціональним, гістохімічним і ультраструктурним особливостям будови різних тканин людини та тварин за цукрового діабету (Мео, 2009; Abdel-Reheim et al., 2014; Rukavina, 2016; Rehman and Akash, 2017). Однак із цілої низки питань, пов'язаних із реакцією нервово-м'язових закінчень та їх мікроциркуляторного русла на гіперглікемію, немає спільної думки, а багато аспектів цієї проблеми потребують подальшого вивчення.

Результати досліджень, проведених окремими авторами (García et al., 2013; Ignacio and Felix, 2016), вказують на те, що цукровий діабет викликає структурні зміни нервово-м'язових закінчень, глибина яких залежить від тривалості гіперглікеміï. Popel' et al. (2017) показали, що підвищений вміст глікозильованого гемоглобіну навіть на короткий термін спричиняє варикозні розширення мієлінових нервових волокон, зменшення площі нервово-м'язових закінчень, а також довжини аксонних терміналей (Konur and Yuste, 2004).

Установлене нами зменшення загальної кількості мієлінових нервових волокон, виявлене морфометричним аналізом препаратів язика, забарвлених за Кульчицьким, вказує на демієлінізацію аксонів уже через чотири тижні після початку моделювання експериментального стрептозотоцинового цукрового діабету, що підтверджується даними інших авторів (Ohnishi et al., 1983), які виявили подібну картину в інших м'язах за цукрового діабету I та II типу. Менша кількість мієлінових нервових волокон великого діаметра та збільшення кількості дрібних нервових волокон із витонченою мієліновою оболонкою порівняно 3 тваринами контрольної групи підтверджує існування процесів демієлінізації вже через шість тижнів після початку моделювання експериментального стрептозотоцинового цукрового діабету.

Характерною картиною за такого діабету вважаємо виявлення підвищеної агрегації філаментозно-тубулярних структур в аксоплазмі термінальних мієлінових нервових волокон. Westfall et al. (2015) пов’язують зростання ступеня агрегації філаментознотубулярних структур в аксоплазмі термінальних мієлінових нервових волокон із порушенням аксонного транспорту. Агрегація мікротрубочок і нейрофіламентів може проходити в місцях підвищеної кислотності аксоплазми. Таке «закиснення», очевидно, - результат зміненої функції нейролемоцитів, які перебувають у неадекватних умовах і виділяють у навколишнє середовище кислий білок (Rosengren et al., 1977; Bera and Nandi, 2014). При цьому в цитоплазмі нейролемоцитів значно збілышується кількість вакуоль, що вказує на критичні процеси споживання рідини з міжклітинного простору, які спостерігали дослідники в інших тканинах за цукрового діабету (Zhou et al., 2011). При цьому мієлінова оболонка має множинні ділянки розшарування ламел мієліну - показник глибокого порушення обміну фосфоліпідів (Grigoletto et al., 2017).

У нервово-м'язових закінченнях зменшується кількість синаптичних пухирців та мітохондрій, які мають просвітлений матрикс $\mathrm{i}$ зруйновані кристи. При цьому нейролемоцити таких нервових волокон містять дрібні гетерохроматизовані ядра, що, на думку Kuznetsov et al. (2016), свідчить про глибоке порушення мітотичної та білоксинтезувальної активності клітини.

Зменшення кількості складок постсинаптичної мембрани важке ускладнення гіперглікемії, що поряд із зменшенням іiї загальної площі спричиняє зниження кількості холінорецепторів (Jonsson and Eriksson, 2007). Якщо врахувати, що при цьому аксоплазма перевантажена синаптичними пухирцями, це в сукупності свідчить про значне порушення механізму екзоцитозу ацетилхоліну через синаптичні мембрани (Azam et al., 2003). 
Виявлена нами деструкція окремих мієлінових нервових волокон викликає денервацію м'язових волокон, що проявляється зменшенням кількості нейролемоцитів у ділянці нервово-м'язових закінчень і аргірофілією їх ядер. Такі зміни спостерігали інші дослідники за порушення структури нервово-м'язових закінчень як при цукровому діабеті (Bril, 2014; Ignacio and Felix, 2016), так i за захворювань іншого генезу (Muntoni, 2012; Oyebode et al., 2012; Silinsky, 2013).

Виявлений нами набряк саркоплазми, який викликає розшарування міофібрил вже через чотири тижні після початку моделювання експериментального стрептозотоцинового цукрового діабету поряд зі значним зменшенням осміофільності нуклеоплазми у м'язових волокнах проміжного типу можна розглядати як прояв функціонального виснаження ядра (Shckorbatov et al., 2010).

Якщо врахувати, що за експериментального стрептозотоцинового цукрового діабету порушується окисний метаболізм (Rehman and Akash, 2017), в якому безпосередню участь беруть мітохондрії (Leem and Koh, 2012), то можна припустити, що атрофія м'язів зумовлена порушенням активного транспорту нейромедіатора в результаті дефіцитного енергозабезпечення аксо-м'язової передачі нервового імпульсу. При цьому відомо, що морфологічний субстрат порушення окисного фосфорилювання - фрагментація та редукція крист, яка проявляється зниженням активності сукцинатдегідрогенази (Carette et al., 2011; Nwayyir, 2017). Кількість мікровезикул із нейромедіатором і кількість мітохондрій у пресинаптичних терміналях аксона залежить, $з$ одного боку, від синаптичної активності нейрона (Crone and Sharma, 2011), з іншого - від швидкості аксонного транспорту (McKelvey, 2014).

Постійна ознака за всіх форм і ступенів нейро- та міопатій недостатність активної передачі імпульсу в зоні пресинаптичної мембрани (Bril, 2014; McKelvey, 2014). Результати, отримані нами, показують, що за експериментального стрептозотоцинового цукрового діабету до наявних деструктивних змін претермінальних нервових волокон і аксональних терміналей приєднується недостатність передачі імпульсів, унаслідок глибоких дегенеративних змін у постсинаптичних мембранах, які посилюють вплив інших несприятливих чинників на стан м'язових волокон. Оскільки на кінцевій стадії дослідження спостерігається тотальна деструкція нервово-м'язових закінчень, морфометричний аналіз провести не вдалося.

Поряд із цим зменшення кількості внутрішьом'язових гемокапілярів викликає значне розширення «зон васкуляризації», що, за даними Popel' et al. (2017), вказує на погіршення трофіки всіх тканин язика, які входять до цієї зони. Збільшення чисельності функціональних артеріоло-венозних анастомозів зумовлюється дією вазоактивних речовин, серед яких неспецифічні метаболіти, гістамін, серотонін, кініни, що у великій кількості утворюються у разі порушення в організмі утилізації глюкози (Pertseva et al., 2013; Nwayyir, 2017). Підвищене скидання артеріальної крові у вени через артеріо-венозні анастомози спричиняють зменшення артеріовенозного градієнта концентрації кисню, порушення окисно-відновних процесів і розвитку ацидозу в навколишніх тканинах (Xie et al., 2014), до якого чутливіші мієлінові нервові волокна порівняно $з$ безмієліновими (Brownlee et al., 1986; Jin et al., 2008; Ishibashi et al., 2016).

Виявлені нами структурно-функціональні зміни мікросудинного русла нервово-м'язових закінчень за експериментального стрептозотоцинового цукрового діабету торкаються не тільки змін ендотеліоцитів, а i їх морфометричного перерозподілу. Зменшення діаметра просвіту складових частин гемомікроциркуляторного русла язика підтверджується даними Tooke (2003) i Popel' et al. (2017), які вказують на виражений метричний перерозподіл гемокапілярів власних м'язів язика за експериментального стрептозотоцинового цукрового діабету. Внаслідок зменшення діаметра вони переповнюються форменними елементами крові, що викликає венозно-капілярний стаз. На думку окремих авторів (Demidova, 2010), тривала венозна гіперемія та стаз зумовлені затриманням продуктів розпаду мієліну та зниженням $\mathrm{pH}$ середовища, в якому закономірно підвищується концентрація кінінів
(Wagner et al., 2008; Xie et al., 2014). Вони викликають парез артеріол, підвищення проникності судин, порушують місцеві ферментативні системи та підвищують чутливість тканин до кисневого голодування (Demidova, 2010).

Після 6-8 тижнів після початку моделювання експериментального стрептозотоцинового цукрового діабету виявлена нами деструкція нервово-м'язових закінчень поряд із гомогенізацією мієлінових оболонок і атрофією термінальних розгалужень аксонів може бути результатом втрати нейротрофічного впливу мотонейрона на м'язові волокна, що залежить від ступеня порушення аксонного транспорту. На це вказує низка досліджень під час його фармакологічної блокади (Borer, 2006; Garcia et al., 2013; McKelvey, 2014). Тому деструкцію аксоплазми за експериментального стрептозотоцинового цукрового діабету слід розцінювати як фактор, який послаблює нейротрофічний вплив на мембрану м'язових волокон.

\section{Висновки}

Проведене нами дослідження дає детальну уяву про динаміку структурно-функціональних змін нервово-м'язових закінчень у різні терміни від початку моделювання експериментального стрептозотоцинового цукрового діабету. В динаміці цього процесу виявляються дві фази: фаза реактивно-адаптаційних змін із максимальною вираженістю через 4 тижні експерименту та деструктивно-дегенеративна фаза, яка розвивається через 6-8 тижнів після початку моделювання експериментального стрептозотоцинового цукрового діабету.

Патоморфологічні зміни відображають структурно-функціональну взаємозумовленість нервово-м’язових закінчень і окремих елементів їх мікроциркуляторного русла, що проявляється їх поєднаною реакцією в різні терміни експериментального стрептозотоцинового цукрового діабету. Зміни в цих структурах спричинюють глибоку морфологічну перебудову м'язових волокон різного фенотипу за експериментального стрептозотоцинового цукрового діабету. Результати наших досліджень показують, що в м'язових волокнах язика разом зі зміненими мітохондріями та міофібрилами містяться пошкоджені органели в аксо-м'язових синапсах з ознаками як реактивних, так і деструктивних процесів. Це вказує на тісний морфофункціональний взаємозв’язок між цими структурами.

За експериментального стрептозотоцинового цукрового діабету відбувається структурна перебудова мієлінових нервових волокон і мікроциркуляторного русла язика з порушенням організації нервово-м'язових закінчень.

\section{References}

Abdel-Reheim, E. S., Abd-Elmoneim, A. A., \& Hosni, A. A. (2014). Fattysucrosed diet/minimal dose of streptozotocin-treated rat: A novel model of gestational diabetes mellitus, metabolic and inflammatory insight. Journal of Diabetes and Metabolism, 5(9), 430-435.

Azam, L., Winzer-Serhan, U., \& Leslie, F. M. (2003). Co-expression of $\alpha 7$ and B2-nicotinic acetylcholine receptor subunit mRNAs within rat brain cholinergic neurons. Neuroscience, 119(4), 965-977.

Bera, A., \& Nandi, P. K. (2014). Nucleic acid induced unfolding of recombinant prion protein globular fragment is $\mathrm{pH}$ dependent. Protein Science, 23(12), $1780-1788$.

Borer, J. (2006). Therapeutic effects of IF blockade: Evidence and perspective. Pharmacological Research, 53(5), 440-445.

Bril, V. (2014). Neuromuscular complications of diabetes mellitus. Continuum: Lifelong Learning in Neurology, 20, 531-544.

Brownlee, M., Vlassara, H., \& Cerami, A. (1986). Trapped immunoglobulins on peripheral nerve myelin from patients with diabetes mellitus. Diabetes, 35(9), 999-1003.

Byrd, J. A., Bruce, A. J., \& Rogers, R. S. (2003). Glossitis and other tongue disorders. Dermatologic Clinics, 21(1), 123-134.

Carette, C., Dubois-Laforgue, D., Gautier, J.-F., \& Timsit, J. (2011). Diabetes mellitus and glucose-6-phosphate dehydrogenase deficiency: From one crisis to another. Diabetes and Metabolism, 37(1), 79-82.

Colev, V. (2008). Experimental models in studies of diabetes mellitus. Pathophysiology, 5, 242. 
Crone, S. A., \& Sharma, K. (2011). Patterning spinal motor activity in the absence of synaptic excitation. Neuron, 71(6), 957-959.

Demidova, T. Y. (2010). Vascular complications of type 2 diabetes mellitus beyond the reach of glycemic control. Diabetes Mellitus, 13(3), 111.

García, M. R., Pearlmutter, B. A., Wellstead, P. E., \& Middleton, R. H. (2013). A slow axon antidromic blockade hypothesis for tremor reduction via deep brain stimulation. PLoS ONE, 8(9), 734-756.

Grigoletto, J., Pukaß, K., Gamliel, A., Davidi, D., Katz-Brull, R., RichterLandsberg, C., \& Sharon, R. (2017). Higher levels of myelin phospholipids in brains of neuronal $\alpha$-synuclein transgenic mice precede myelin loss. Acta Neuropathologica Communications, 5(1), 1-10.

Ignacio, A. B., \& Felix, L. S. (2016). Diabetes mellitus and neuromuscular blockade: Review. Journal of Diabetes and Metabolism, 7(6), 1-8.

Ishibashi, F., Kojima, R., Taniguchi, M., Kosaka, A., Uetake, H., \& Tavakoli, M. (2016). The expanded bead size of corneal c-nerve fibers visualized by corneal confocal microscopy is associated with slow conduction velocity of the peripheral nerves in patients with type 2 diabetes mellitus. Journal of Diabetes Research, 20(16), 1-9.

Jackowiak, H., Skieresz-Szewczyk, K., Kwieciński, Z., Godynicki, S., Jackowiak, K., \& Leszczyszyn, A. (2014). Light microscopy and scanning electron microscopy studies on the reduction of the tongue microstructures in the white stork (Ciconia ciconia, Aves). Acta Zoologica, 96, 436-441.

Jin, H. Y., Piao, M. H., Kim, S. Y., Kang, S. M., Kim, C. H., Kim, D. Y., Park, J. H., Baek, H. S., \& Park, T. S. (2008). The morphological observation of gastric nerve fibers in experimental animals and people with diabetes. Diabetes Research and Clinical Practice, 79, 84-85.

Jonsson, M., \& Eriksson, L. I. (2007). Role of presynaptic acetylcholine autoreceptors at motor nerve endings on tetanic and train-of-four fade seen during a nondepolarizing neuromuscular block. Anesthesiology, 106(6), 1243-1244.

Konur, S., \& Yuste, R. (2004). Imaging the motility of dendritic protrusions and axon terminals: Roles in axonsampling and synaptic competition. Molecular and Cellular Neuroscience, 27(4), 427-440.

Kuznetsov, K. A., Shckorbatov, Y. G., Kolchigin, N. N., \& Nikolov, O. T. (2016). Changes of chromatin and cell membranes in exfoliated human buccal epithelium cells exposed to non-ionizing and ionizing electromagnetic fields. Conference Paper published Sep 2016 in 2016 8th International Conference on Ultrawideband and Ultrashort Impulse Signals (UWBUSIS).

Leem, J., \& Koh, E. H. (2012). Interaction between mitochondria and the endoplasmic reticulum: Implications for the pathogenesis of type 2 diabetes mellitus. Experimental Diabetes Research, 20(12), 1-8.

McKelvey, C. (2014). Axon transport deficits: Neurodegeneration's first sign? Multiple Sclerosis Discovery Forum, 12, 1-10.

Meo, S. A. (2009). Diabetes mellitus: Health and wealth threat. International Journal of Diabetes Mellitus, 1(1), 42

Muntoni, F. (2012). Novel neuromuscular diseases. Neuromuscular Disorders, 22(9-10), 804.

Nwayyir, H. A. (2017). Is glucose-6-phosphate dehydrogenase deficiency a risk factor for proliferative diabetic retinopathy in male patients with type 1 diabetes mellitus in basrah? Journal of Medical Science and Clinical Research, 5(1), 15173-15179.

O’Reilly, D., \& Long, R. G. (2008). Diabetes and the gastro-intestinal tract. Digestive Diseases, 5(1), 57-64.

Ohnishi, A., Harada, M., Tateishi, J., Ogata, J., \& Kawanami, S. (1983). Segmental demyelination and remyelination in lumbar spinal root of patients dying with diabetes mellitus. Annals of Neurology, 13(5), 541-548.
Oyebode, O. R. O., Hartley, R., Singhota, J., Thomson, D., \& Ribchester, R. R. (2012). Differential protection of neuromuscular sensory and motor axons and their endings in WldS mutant mice. Neuroscience, 200, 142-158.

Pertseva, M. N., Kuznetsova, L. A., \& Shpakov, A. O. (2013). New conceptual approach for search for molecular causes of diabetus mellitus, based on study of functioning of hormonal signaling systems. Journal of Evolutionary Biochemistry and Physiology, 49(5), 457-468.

Popel', S. L., Baskevich, O. V., Zhurakivskyi, V. M., Zhurakivska, O. Y., Melnik, I. V., Krasnopolskiy, S. Z., \& Atamanchuk, O. V. (2017). Three-dimensional structure of the lingual papillae of healthy rats and rats with experimental diabetes mellitus (in the context of mechanism of development of diabetic glossitis. Regulatory Mechanisms in Biosystems, 8(1), 58-65.

Pourlis, A. F. (2014). Morphological features of the tongue in the quail (Coturnix coturnix japonica). Journal of Morphological Sciences, 31(3), 177-181.

Rehman, K., \& Akash, M. S. H. (2017). Mechanism of generation of oxidative stress and pathophysiology of type 2 diabetes mellitus: How are they interlinked? Journal of Cellular Biochemistry, 99, 1-9.

Rezki, A., Merioud, B., Delmas, D., Cyril, C., Scheiwiller, R., Leblé, R., \& Valensi, P. (2016). Sequential compression/decompression by a pulsating suit increases cutaneous microcirculatory blood flow in patients with type 2 diabetes. Diabetes and Metabolism, 42(4), 298.

Rosengren, L., Wronski, A., Haglid, K. G., Jarlstedt, J., \& Rönnbäck, L. (1977). Amino acid incorporation into total protein and levels of S-100 protein in discrete rat brain areas after prolonged protein or amino acid restriction. Journal of Neuroscience Research, 3(2), 153-161.

Rukavina, M. (2016). Typ-1-Diabetes - Verhältnis Proinsulin/C-Peptid mit Pathogenese Assoziiert. Diabetologie und Stoffwechsel, 11(6), 384-396.

Sanders, I., \& Mu, L. (2013). A three-dimensional atlas of human tongue muscles. Anatomical Record, 296(7), 1102-1114.

Semenko, V. V., \& Savytskyi, I. V. (2017). Development of experimental model of diabetes mellitus. Journal of Endocrinology, 13(4), 276-280.

Shckorbatov, Y., Rudneva, I., Pasiuga, V., Grabina, V., Kolchigin, N., Ivanchenko, D., Kazanskiy, O., Shayda, V., \& Dumin, O. (2010). Electromagnetic field effects on Artemia hatching and chromatin state. Open Life Sciences, 5(6).

Silinsky, E. M. (2013). Low-frequency neuromuscular depression is a consequence of a reduction in nerve terminal $\mathrm{Ca}^{2+}$ currents at mammalian motor nerve endings. Anesthesiology, 119(2), 326-334.

Tooke, J. E. (2003). The microcirculation in diabetes mellitus. International Textbook of Diabetes Mellitus.

Uemura, M., Tamada, Y., \& Suwa, F. (2009). Morphological study of the connective tissue papillae and the capillary loops on the lingual dorsum in the type 2 diabetes mellitus model rats. Okajimas Folia Anatomica Japonica, 85(4), 139-149.

Wagner, O. F., Nowotny, P., Vierhapper, H., \& Waldhäusl, W. (2008). Plasma concentrations of endothelin in man: Arterio-venous differences and release during venous stasis. European Journal of Clinical Investigation, 20(5), 502-505.

Westfall, S., Lomis, N., Singh, S. P., Dai, S. Y., \& Prakash, S. (2015). The gut microflora and its metabolites regulate the molecular crosstalk between diabetes and neurodegeneration. Journal of Diabetes and Metabolism, 6(8), 577-580.

Xie, X.-J., Hu, Y., Cheng, C., Feng, T.-T., He, K., \& Mao, X.-M. (2014). Should diabetic ketosis without acidosis be included in ketosis-prone type 2 diabetes mellitus? Diabetes/Metabolism Research and Reviews, 30(1), 54-59.

Zhou, C., Gilbert, J. D., \& Byard, R. W. (2011). How useful is basal renal tubular epithelial cell vacuolization as a marker for significant hyperglycemia at autopsy? Journal of Forensic Sciences, 56(6), 1531-1533. 